\title{
The Leslie Kimberlite Pipe of Lac de Gras, Northwest Territories, Canada: Evidence for Near Surface Hypabyssal Emplacement
}

Berg, G.W. ${ }^{1}$ and Carlson, J.A. ${ }^{2}$

1. Dept of Geological Sciences, University of Cape Town, 7700 Rondebosch, S. Africa

2. BHP Minerals Canada Ltd., \#8 - 1699 Powick Road, Kelowna, British Columbia, Canada

\section{Introduction}

The 7 hectare Leslie pipe is filled with hypabyssal kimberlite to the present land surface, with the exception of a narrow remnant of tuffisitic kimberlite breccia (TKB) intersected on the pipe contact at a vertical depth of approximately 400 meters. Geological evidence suggests that erosion of the emplacement age surface has been relatively minimal (several hundred meters?). Considered together, these points are in contrast to the widespread observation that kimberlite pipes are filled with TKB underlain by a hypabyssal root zone (Hawthorne, 1975; Mitchell, 1986), and pose several questions:

- Does the Leslie hypabyssal kimberlite chemistry differ substantially from the hypabyssal root zones of the type area of Kimberley, South Africa, which might account for high level magmatic instead of explosive emplacement?

- Alternatively, does the geochemical evidence imply that there must have been an overlying explosive phase at Leslie, which, in turn, suggests a deeply eroded pipe?

- Is the pipe filled by a single or by multiple emplacement hypabyssal phases?

Thin section petrography and geochemistry were utilized to address these problems. Ninety-three samples were prepared from NQ drill core of six radially oriented drill holes (Figure 1).

\section{Petrography}

Most of the Leslie material is exceptionally fresh hypabyssal macrocrystic monticellite kimberlite. Olivine macrocrysts exhibit a considerable size range with longest dimensions up to about $15 \mathrm{~mm}$. Some bore holes appear to contain distinctive macrocryst size ranges. For example, the large olivine macrocrysts (long dimension) range from $4-13 \mathrm{~mm}$ for LDC-07 $(120 \mathrm{~m})$ and range from $3-5 \mathrm{~mm}$ for LDC-09 $(140 \mathrm{~m})$. Alteration of olivine to serpentine is relatively sparse. Strongly altered orthopyroxene macrocrysts are present, but rare.

Olivine micro-phenocrysts, monticellite, calcite, perovskite and opaques dominate the groundmass, with minor phlogopite and apatite. Monticellite is typically very fresh. $\mathrm{Ca}-\mathrm{Mg}$ silicate with optical properties of monticellite also occurs as rare reaction rinds on and optically continuous with rounded olivine macrocrysts, and as rare phenocrysts with olivine cores.

Sparse to severe contamination by country rock is evident in some samples. This is reflected in the chemistry discussed later.

Tuffisitic kimberlite breccia (TKB) encountered in drill hole LDC-03 at $400 \mathrm{~m}$ is strongly altered but identifiable by the presence of rare pelletal lapilli. Pelletal rinds consist of altered micro-phenocrysts in an unresolved fine-grained brown groundmass. Contamination of TKB by country rock is partly obscured by alteration, but is clearly reflected in the TKB geochemistry. 


\section{Geochemistry and Comparison with the Type Area}

Leslie hypabyssal kimberlite (Table 1, Analyses 1 and 2), which has a comparable petrography to that of Dutoitspan hypabyssal kimberlite (Analysis 3), reveals no chemical differences that would suggest a unique magmatic behaviour at Leslie. Notice in particular the low $\mathrm{Na}_{2} \mathrm{O}$ contents at Leslie.

Analysis 1 is considered to represent minimally or un-contaminated hypabyssal kimberlite. Small systematic increases in the concentrations of $\mathrm{SiO}_{2}$ and $\mathrm{Al}_{2} \mathrm{O}_{3}$, noted in numerous Leslie hypabyssal samples when compared to Analysis 1 , probably reflect minor contamination by TKB.

Leslie TKB (Analysis 4) reflects contamination and alteration effects analogous to Bultfontein TKB; in particular enhanced $\mathrm{Al}_{2} \mathrm{O}_{3}$ and $\mathrm{Na}_{2} \mathrm{O}$ concentrations. This is not surprising as the Leslie wall rock is granitoid and the Bultfontein wall rock is shale and basic lava underlain by granitoid.

Table 1: Representative Leslie bulk rock analyses and comparative data.

\begin{tabular}{|l|l|l|l|l|l||}
\hline & \multicolumn{1}{|c|}{1} & \multicolumn{1}{c|}{2} & \multicolumn{1}{c|}{3} & \multicolumn{1}{c|}{5} \\
\hline \hline ELEMENT & LDC-07 220 & LDC-09140 & KDT 25 & LDC-03 427 & KBULT 28 \\
\hline $\mathrm{SiO}_{2}$ & 31.67 & 32.71 & 31.73 & 43.00 & 39.28 \\
\hline $\mathrm{TiO}_{2}$ & 0.66 & 0.52 & 1.55 & 0.21 & 0.55 \\
\hline $\mathrm{Al}_{2} \mathrm{O}_{3}$ & 1.23 & 1.51 & 1.94 & 2.40 & 5.97 \\
\hline $\mathrm{Fe}_{2} \mathrm{O}_{3}$ & 9.24 & 8.65 & 8.76 & 7.42 & 7.74 \\
\hline $\mathrm{MnO}$ & 0.17 & 0.16 & 0.16 & 0.11 & 0.13 \\
\hline $\mathrm{MgO}$ & 40.93 & 39.53 & 36.17 & 34.27 & 26.31 \\
\hline $\mathrm{CaO}$ & 8.09 & 8.40 & 7.98 & 4.28 & 4.56 \\
\hline $\mathrm{Na} 2 \mathrm{O}$ & 0.00 & 0.03 & 0.37 & 2.55 & 1.58 \\
\hline $\mathrm{K}_{2} \mathrm{O}$ & 0.397 & 0.266 & 0.74 & 3.217 & 1.50 \\
\hline $\mathrm{P}_{2} \mathrm{O}_{5}$ & 0.258 & 0.400 & 0.80 & 0.337 & 0.53 \\
\hline $\mathrm{NiO}$ & 0.216 & 0.213 & 0.19 & 0.213 & 0.16 \\
\hline $\mathrm{Cr}_{2} \mathrm{O}_{3}$ & 0.340 & 0.353 & 0.32 & 0.188 & 0.18 \\
\hline $\mathrm{H}_{2} \mathrm{O}-$ & 0.66 & 0.44 & 0.68 & 0.36 & 5.18 \\
\hline $\mathrm{LOI}$ & 5.59 & 6.26 & 9.85 & 2.08 & 7.21 \\
\hline $\mathrm{TOTAL}$ & 99.45 & 99.44 & 101.24 & 100.64 & 100.88 \\
\hline
\end{tabular}

1, 2: Leslie hypabyssal; 3: du Toitspan, Kimberley, hypabyssal;

4: Leslie TKB; 5: Bultfontein, Kimberley, TKB.

\section{Single or multiple hypabyssal phases?}

Samples deemed heavily contaminated by veining, county rock or alteration were excluded from statistical analysis (leaving $\mathrm{n}=70$ analyses, from six bore holes). For initial statistical purposes, individual drill holes (Figure 1) were treated as potential sub-populations within the pipe.

There are some subtle but statistically significant variations in element concentrations between bore holes. For example, drill hole LDC-07 is strongly biased towards the low end of the $\mathrm{SiO}_{2}$ range of the combined drill holes. LDC-04 is also significantly lower in $\mathrm{SiO}_{2}$ than the remaining drill holes if LDC-07 is removed from the data set. Further significant differences include relatively low $\mathrm{P}_{2} \mathrm{O}_{5}$ and high $\mathrm{TiO}_{2}$ concentrations in LDC-07 compared to the other drill holes. 
There are no clear-cut petrographic or geochemical distinctions to indicate more than one hypabyssal phase. The minor differences described could either represent variations within a single hypabyssal phase or could imply multiple intrusions of chemically similar magma batches.

\section{Suggested emplacement model for Leslie}

The presence at Leslie of TKB at $400 \mathrm{~m}$, combined with normal type-area hypabyssal geochemistry and a classic carrot-shaped pipe with steep inward-sloping walls, suggests that initially Leslie conformed to the pipe forming mechanisms common to TKB-filled pipes. Leslie either blew an open vent subsequently filled by magmatic kimberlite, or magma displaced an earlier TKB fill. The enigma lies in the apparent close coincidence of the present with the emplacement-age land surface. $\mathrm{Rb}-\mathrm{Sr}$ systematics on phlogopite macrocrysts indicate an age of $53.9 \pm 2.0 \mathrm{Ma}$ for Leslie hypabyssal as compared to 53.2 $\pm 3.8 \mathrm{Ma}$ for Panda crater facies kimberlite (Collerson, 1995 pers. comm.). The Panda pipe, located $6 \mathrm{~km}$ northeast of Leslie, is composed of crater facies kimberlite to a depth of at least $300 \mathrm{~m}$ and is also emplaced in porphyritic biotite granite (Carlson et. al, 1998).

Mitchell (1986, p.34) notes that "Pyroclastic volcanism is not followed by upwelling of magma to form crater lava lakes, and the establishment of a conduit filled with magmatic kimberlite does not occur". Mitchell (1986, p.343) further reviews laboratory experiments from $4 \mathrm{~kb}$ down to $0.5 \mathrm{~kb}$ which clarify why kimberlite lavas are not found on the surface. The lowest volatile pressure required to keep kimberlite fluid is not known, but the presence of some overlying material seems inescapable to explain the maintenance of sufficient volatile pressure to allow intrusion of the large volumes of magmatic kimberlite observed at Leslie. The possibility of mechanical over-pressure influencing the hypabyssal intrusion of small volumes of kimberlite to shallow levels warrants consideration.

\section{References}

Carlson, J.A., Kirkley, M.B., Thomas, E.M., and Hillier, W.D., 1998, Recent Major Kimberlite Discoveries in Canada: this volume.

Hawthorne, J.B., 1975, Model of a kimberlite pipe: Phys. Chem. Earth Vol. 9, p. 1 - 15.

Mitchell, R.H., 1986, Kimberlites: mineralogy, geochemistry, and petrology. Plenum Press, 442 p.

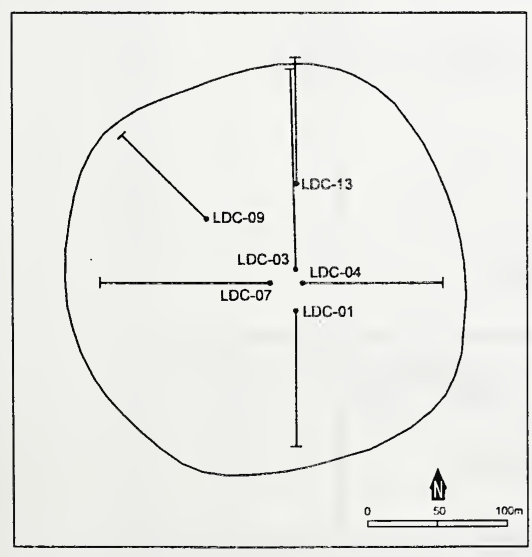

Figure 1. Plan map of Leslie kimberlite. 